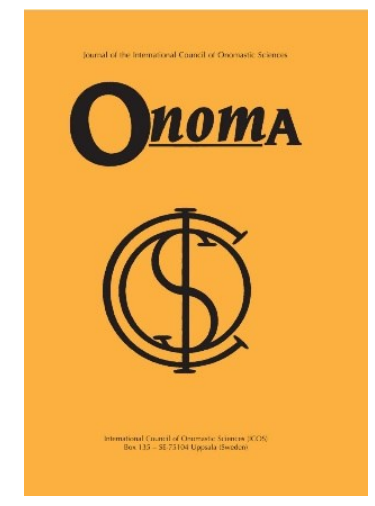

Onoma 54

Journal of the International Council of Onomastic

Sciences

ISSN: 0078-463X; e-ISSN: 1783-1644

Journal homepage: https://onomajournal.org/

\title{
Commemorative street names in Languedoc: Reviving the spirit, elevating the mind and strengthening patriotism
}

DOI: 10.34158/ONOMA.54/2019/12

\section{Rex Taylor}

Emeritus Professor

University of Glasgow

2/1 134 Dowanhill Street

Glasgow

G12 9DN

Rex.taylor@glasgow.ac.uk

To cite this article: Taylor, Rex. 2019. Commemorative street names in

Languedoc: Reviving the spirit, elevating the mind and strengthening patriotism. Onoma 54, 221-241. DOI: 10.34158/ONOMA.54/2019/12

To link to this article: https://doi.org/10.34158/ONOMA.54/2019/12

(C) Onoma and the author.

Commemorative street names in Languedoc: Reviving the spirit, elevating the mind and strengthening patriotism

Abstract: This study treats street names as "memory places" of local and national identity. Following a historical review of naming and renaming streets in France, the study focuses on commemorative street names in Languedoc. In a sample of over 1000 street names frequencies are presented for those named after individuals (by occupational background and reputational status) and for national events (including the Revolution and First Republic and the two world wars). Also explored are differences in commemorative emphasis between villages and towns in Languedoc. Each village is located on three separate commemorative axes - Revolutionary/ Ancient Regime, men of ideas/men of action and regional/international significance. Position on these axes result in a commemorative profile for each village and show some to be highly distinctive. Reasons for the different profiles are explored.

Keywords: Commemorative, street names, memory place, cultural identity. 


\section{Les noms de rues commémoratives dans le Languedoc : Revivre l'esprit, élever la pensée, renforcer le patriotisme}

Résumé : Cette étude approche les noms de rues comme des «lieux de mémoire » de l'identité locale et nationale. Suivant une revue historique des nominations et re-renominations des rues de France, cet article se concentre sur les noms de rues commémoratives du Languedoc. Sur un échantillon de plus de 1000 noms de rues, il y est présenté les fréquences des rues qui portent le nom de personnes (selon leur profession ou leur réputation) et des évènements nationaux (incluant la Révolution, la Première République ainsi que les deux guerres mondiales). Un panthéon du Languedoc commémorant ces noms de rues est comparé au panthéon national. Les différences d'emphase commémorative entre les villages et les villes du Languedoc sont également explorées. Pour chaque village, les noms de rues commémoratives se situent sur trois axes différents : révolution/ancien régime ; homme d'action/homme d'idée ; significativité régionale/internationale. Le positionnement sur ces axes permet d'identifier des profils commémoratifs distincts pour beaucoup de villages. Les raisons de ces profils distinctifs sont explorées.

Mots-clés : Commémorative, noms de rues, lieux de mémoire, identité culturelle.

\section{Straßennamen des Gedenkens in Languedoc: Wiederbelebung des Geistes, Erhöhung des Geistes und Stärkung des Patriotismus}

Zusammenfassung: Diese Studi e behandelt Straßennamen als „Erinnerungsorte“ der lokalen und nationaler Identität. Nach einer historischen Überprüfung der Benennung und Umbenennung von Straßen in Frankreich konzentriert sich die Studie auf Gedenkstraßennamen im Languedoc. In einer Stichprobe von über 1000 Straßennamen werden Frequenzen für nach Personen benannte Personen (nach beruflichem Hintergrund und Reputationsstatus) und nach nationalen Ereignissen (einschließlich der Revolution und der Ersten Republik sowie der beiden Weltkriege) angegeben. Untersucht werden auch Unterschiede in der Betonung der Gedenkfeierlichkeiten zwischen Dörfern und Städten im Languedoc. Jedes Dorf liegt auf drei separaten Gedenkachsen - Revolutionäres / Ancien-Regime, Männer der Ideen / Männer der Aktion und regionale / internationale Bedeutung. Die Position auf diesen Achsen ergibt ein Erinnerungsprofil für jedes Dorf und zeigt, dass einige sehr unterschiedlich sind. Gründe für die unterschiedlichen Profile werden untersucht.

Schlüsselbegriffe: Gedenk, Straßennamen, Erinnerungsorte, Kulturelle Identität. 


\section{Commemorative street names in Languedoc: Reviving the spirit, elevating the mind and strengthening patriotism}

REX TAYLOR

\section{Introduction}

In Languedoc, as elsewhere in France, the first streets were named after prominent topographical features, human activities associated with them, and to indicate the direction of neighbouring settlements. The first streets to be named after individuals were named for kings and queens, followed by those commemorating saints, church dignitaries, aristocrats and powerful landowners.

With the revolution of 1789 everything changed. All prefixes referring to elements of the Ancient Regime (e.g. Saint/Sainte, Roi/Reine, Eglise) were prohibited. In their place, names were sought to celebrate the new age. One of the early Revolutionaries wrote to his fellow Jacobins:

Brothers and friends. I have taken the liberty of removing the inscription "Quai des Theatins" from the corner of my house and substituting "Quai de Voltaire" [...]. We will always have a Voltaire, and we shall never again have Theatins (a religious order). I invite the good patriots of the rue Platriere to put the name, Jean-Jacques Rousseau on the corners of their houses. It is important that sensitive hearts and ardent souls should think, in crossing this street, that Rousseau lived here on the fourth floor, while it is of little importance to know that people used to make plaster on this street. (Lacombe 1886: 104)

But such piece-meal alterations, could not satisfy a regime which sought to Republicanise the whole of French life. Accordingly, the Committee for the Instruction of the Public invited the abbé Henri Grégoire to draw up a comprehensive plan for strengthening Republicanism through the naming and renaming of buildings, monuments and streets. Gregory's Report, adopted in 1794 , called for names which had the power to act as "vehicles for thought", reminding all citizens of their new rights and responsibilities, and, above all, of their precious Liberty. Specifically, in relation to streets, he called for names which were capable of "reviving the spirit, elevating the mind and strengthening patriotism" (Grégoire 1794: 15).

Grégoire's exhortation went out to every commune in France, and in Languedoc, there are still streets named after him in Marseillan and SainteAndré-de-Sangonis (Figure 1). 


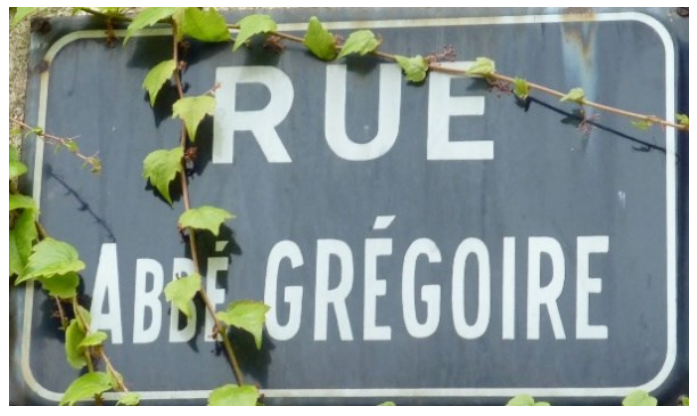

Figure 1: Marseillan street sign, author's photo.

Overall, the names of 31 towns and villages in Languedoc were changed (e.g. Nézignan-l'Évêque became Nézignan-le-Libre), and within all villages, street names were changed to celebrate Revolutionary ideals, events and leaders. Most Languedoc villages have street names celebrating the ideals of the First Republic (rues de la Liberté, Égalité and Fraternité), just as they have a rue de la République and a rue Quatorze Juillet to celebrate the fall of the Bastille. Many have streets named after leading Republican figures such as Robespierre, Mirabeau and Lafayette and some still have streets named after the months of the Republican calendar, as in the two Florensac street signs (Figures 2 and 3).

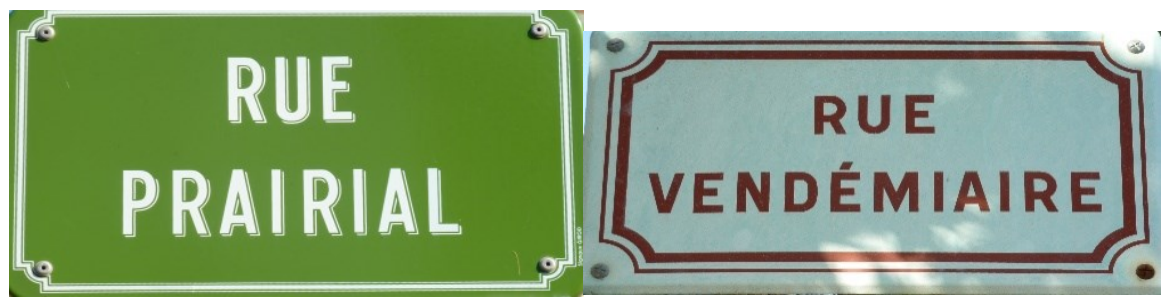

Figures 2 and 3: Florensac street signs, author's photo.

The attempts of post-Revolutionary governments to repudiate the past and legitimate the present were reflected in a succession of street-name changes.

The First Empire (1804-1815) came to terms with the Ancient Regime, mainly by reinstating some of the ecclesiastical street names (Montagnac still has streets commemorating the Saintes Eloi, Clair, Jacques and Thomas) and the Regime celebrated itself in naming streets after Napoleonic victories. After 1815 , most street names with Napoleonic connotations reverted to their pre1791 names. Changes in the name of what is presently the Place de la République in Bédarieux serves as a particular example of these "baptisms" and "re-baptisms". In the 17th and 18th centuries it was called the Place de la Fort, this changed to the Place de la Liberté in 1789, to the Place Royal in 1815, to the Place d'Orléans in 1830, to the Place de la République in 1848, to the Place Napoléon in 1852 and back to the Place de la République in 1870. 
The Second Republic (1848-1852) and the Second Empire (1852-1870) reinstated the street names celebrating Napoleonic victories, but the change was short-lived because the Third Republic (1870-1940) set about replacing them with names to commemorate its own leading figures (such as Jean Jaurès, Louis Blanc, Jules Ferry, Léon Gambetta). Moreover, to give added legitimacy to its self-proclaimed revolutionary character, streets were named and renamed to celebrate the ideals of the revolution and the First Republic (Figures 4 and 5). As a result of this practice, many of the street names which are redolent of Revolutionary times actually date from the years of the Third Republic. Raul Morand's 1906 pamphlet, "On the instruction of the masses through things of greatest utility: Street signs", is indicative of the times. He argued that "for honour to persist in human memory" (1906: 24), it was necessary not only to name streets after honourable individuals, but also to summarise their accomplishments, so that the streets would constitute, "a dictionary for the child, the passing workman and the foreigner" (1906: 26). The sentiment here is identical to that expressed by Henri Grégoire over a hundred years earlier. While it is impossible to measure the influence of Morand's, and similar appeals, the influence of the First Republic on the Third is clear.

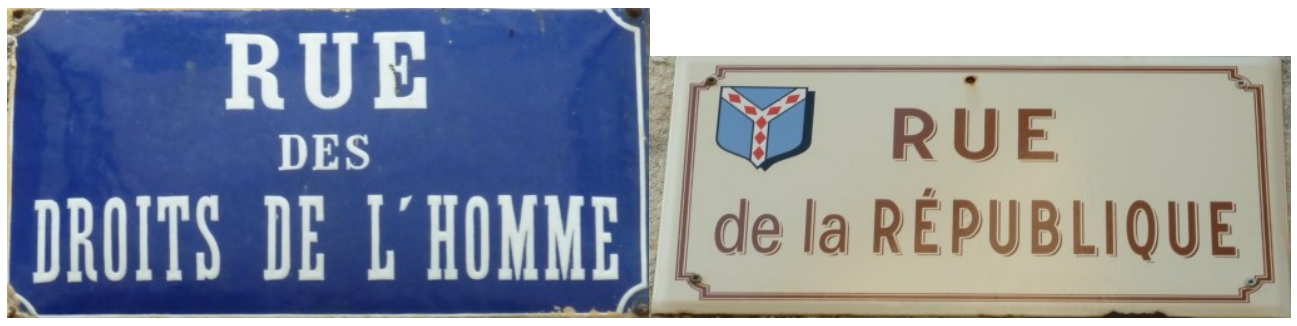

Figures 4 and 5: Republican street signs, author's photos.

The naming and renaming of streets coincided with the rapid industrialization and urbanization of France. New streets were being built and named. In addition to commemorating politicians and revolutionaries, the street names now celebrated French cultural figures; writers like Victor Hugo and Émile Zola, scientists like Louis Pasteur, Pierre and Marie Curie and artists like Toulouse-Lautrec and Paul Gauguin.

The First and Second World Wars were also a source of inspiration for street names. Most villages in Languedoc have a rue de Verdun, an Avenue Huit Mai (Victory in Europe) or a Place Onze Novembre (Armistice Day). The generals Foch, Joffre and Leclerc are remembered in most village street names. Two other wartime figures, Charles de Gaulle and his resistance leader, Jean Moulin, are commemorated in street names throughout Languedoc.

Post-Second World War reconstruction resulted in a further bout of street naming. National cultural figures such as Jean-Paul Sartre, André Malraux and Simone de Beauvoir are celebrated in street names throughout France, and in 
Languedoc they are joined by more regional figures such as George Brassens and Marcel Pagnol.

Three further trends in street naming can be detected. First, there has been a form of democratisation as streets have been named after sportsmen (such as Eric de Taberlay, Henri Ferrari and Xavier Lapeyre), popular entertainers (such as Edith Piaf, Jacques Brel and Bobbie Lapointe) and film directors (e.g. François Truffaut or Claude Chabrol). The second trend is an increasing internationalization of street names. World statesmen such as Churchill, Kennedy, Salvador Allende and Nelson Mandela are celebrated in Languedoc street names, and there are also many references to Europe (such as rondpoint d'Europe and Place de Europe). The final trend, particularly observable in the lotissements that now surround most villages, is a celebration of the vine and its continuing role in the economy of the region. There are streets generically named Les Vigne, but in many villages the individual grape varieties are celebrated. For example, in Sauvian, there are rues des Merlot, Cabernet, Chardonnay and Sauvignon. The village of Sérignan also celebrates these varieties but has, in addition, rues des Carrignan, Cinsault and Muscat.

A distinction has been made between those street names that are indigenous and reflect the local topography, and those that have been imposed and commemorate elements of French history. The indigenous/topographical street names still constitute around half of all street names in the towns and villages of Languedoc. The imposition of street names commemorating national events and figures has occurred over the last two hundred years, principally in four phases - each accounting for an unequal proportion of the total number of commemorative street names. Those relating to the Revolution and the First Republic account for around 1 in 5 of all commemorative names, those relating to the Third Republic account for around 1 in 2, those relating to the first and second World Wars around 1 in 5 and those relating to postSecond World War events and personalities around 1 in 10.

\section{Street names as "memory places"}

From the foregoing historical review, it is clear that commemorative street names are the result of a number of naming processes. Some were named contemporaneously for a person or an event, others were named long after the person died or the event occurred. Some acts of commemoration were the outcome of popular feeling and some the outcome of decisions by a committee or even a single individual, usually a mayor. Moreover, there has also been a good deal of re-naming of streets to reflect new socio-political realities.

These separate processes notwithstanding, commemorative street names have an overall cultural significance because, collectively, they reflect sociopolitical realities and changes in the society as a whole. Not just French society, 
but all societies undergoing change. The commemorative processes observed for France have also been observed in a number of Baltic and East European towns and cities following the collapse of state socialism in 1989 (Ainiala \& Vuolteenaho 2009).

Beyond Europe, there are now good onomastic studies of street names in the creation and recreation of public space in Iran, Israel, South East Asia and Africa (Rose-Redwood et al. 2018).

In the Foreword to the magisterial volume Onomastics in contemporary public space, edited by Oliviu Felecan \& Alina Bugheșiu, Felecan (2013: X) makes the claim that "sociocultural changes are almost unmediatedly mirrored by onomastics" (my italics). This claim is substantiated in an impressive range of studies which push the boundaries of what is understood by onomastics in the public space. In this, and Unconventional anthroponyms: Formation patterns and discursive function, Felecan \& Felecan (2014) provide an imaginative resource and benchmark for future studies. The present study contributes to this corpus by drawing on a distinctively French approach, rooted not in linguistics but in cultural history. This approach was pioneered by the historian Pierre Nora and his inter-disciplinary colleagues at the Sorbonne (Nora 1986).

Their central concept, memory place, is any significant entity, whether material or non-material, which by dint of human will or the work of time, has become a symbolic element in the heritage of any community. They have identified a wide range of these "memory places" and perceptual triggers of French national identity - places with symbolic meaning (e.g. Verdun and Reims), historical figures (e.g. Joan of Arc) literary and artistic objects (e.g. Proust's Remembrance of Things Past) emblems and symbols (e.g. the French Tricolour and the Marseillaise).

Street names are a good example of these memory places and for any village, town or city, they reflect and preserve the way in which it thinks about itself and wishes to see itself remembered.

Viewed in this way, street names also constitute a point of entry to understanding a society. They are to the sociologist what barium meal is to the radiographer. Imagine two towns. In town A most of the streets are named after saints and royal personages. In town B most of the streets are named after individuals who have achieved prominence in their own lives. On the basis of their street names, town A reflects stability and order, while town B reflects individualism and change.

Of course, it is rarely as clear-cut as this. Street names of most towns reflect a mixture of stability and change, but the balance between the two provides clues to social and political structures. The frequent changes in street names potentially complicates the situation, but the naming and renaming of streets provides insight into the circulation of national elites and the ways in which they attempt to legitimate their power. Street names are also important 
cultural indicators. Like monuments and other elements of the urban scene, they contribute to the symbolic capital which cities, towns and villages increasingly draw upon in their attempts to promote and market themselves.

\section{Street names in Languedoc $-\mathbf{A}$ qualitative analysis}

The present study is based on a sample of 20 towns situated on the Mediterranean littoral, between Béziers and Montpellier ${ }^{1}$. They vary in size between Montblanc, with a population of 2,814 in 70 streets and Frontignan, with a population of 22,896 in 416 streets. There are 3,150 streets in the sample as a whole.

Just over half of the street names are descriptive/topographical, in the sense that they relate to the locality, and just under half have been classified as commemorative, in the sense that they commemorate people, events and places of national and/or regional significance. There are a few streets, under 4 percent, which fall outside this binary classification e.g. streets named after flowers and animals, they have been excluded from the subsequent analysis.

The distinction between descriptive and commemorative names is straightforward in relation to those streets named after people. The French practice, almost universal ${ }^{2}$, is to use both personal and family name in street designation. Titles are also included, as in the photo in Figure 6 below.

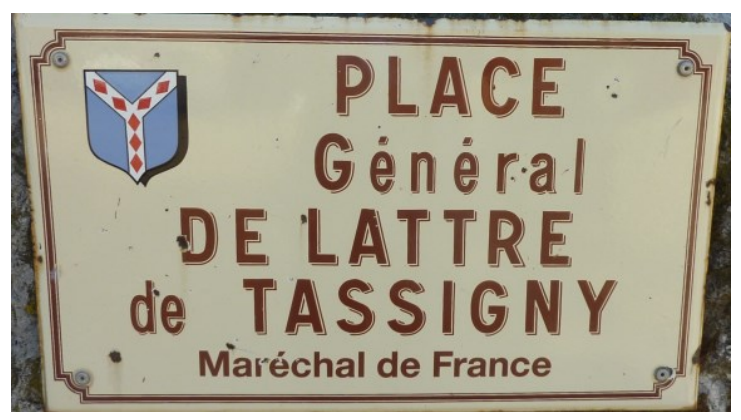

Figure 6: Montblanc street sign, author's photo.

Thus, the distinction between a rue Moulin (descriptive/topographical) and a rue Jean Moulin (commemorative) presents no difficulties. Distinction

\footnotetext{
1 In an earlier paper (Forthcoming) Professor Taylor explored differences in street names between Montblanc, France and Dumfries, Scotland. The present paper focuses exclusively on commemorative street names in Languedoc and shows their wider historical and social significance. It should be read as an onomastic approach to French history rather than a study of onomastics, per se.

2 Revolutionary figures, such as Mirabeau, Voltaire and Rabelais are rarely given a first name, but later figures rarely appear without both names. This paper reflects actual usage in street names.
} 
between descriptive/topographical and commemorative street names relating to place is more difficult, relying on knowledge of French geography and history. Thus, a rue de Béziers in Montblanc or a rue de Sète in Mèze relates to the nearby towns (descriptive/topographical) whereas a rue Verdun in any part of Languedoc relates to a place hundreds of kilometres away and having historical and national significance (commemorative).

The subsequent analysis relates exclusively to the 1,459 streets with names defined as commemorative.

Overall, the proportion of commemorative streets named after people $(81 \%)$ is substantially greater than the proportion named after events $(13 \%)$ and places $(6 \%)$. The analysis begins with the identification of those individuals most celebrated in Languedoc street names.

\subsection{The Pantheon}

Table 1 provides three measures of celebrity. The first column shows the number of villages (out of 20) having a street named after each of the six most celebrated individuals, the second column lists the total number of streets named after each individual (the difference between the two being accounted for by the naming of two of more streets after the same individual e.g. Capestang has a Place, a rue and an Impasse all named after Léon Gambetta ).

Table 1: The Languedoc Pantheon

\begin{tabular}{|l|l|l|l|}
\hline & Number of towns & Number of streets & Main thoroughfare \\
\hline Jean Jaurès & 17 & 22 & 15 \\
\hline Victor Hugo & 16 & 21 & 17 \\
\hline Jean Moulin & 16 & 20 & 15 \\
\hline Louis Pasteur & 18 & 20 & 10 \\
\hline Voltaire & 16 & 19 & 6 \\
\hline Léon Gambetta & 15 & 19 & 11 \\
\hline
\end{tabular}

The third column gives an indication of the prominence of streets so named - as indexed by the number of those which are main thoroughfares (avenues, boulevards and places).

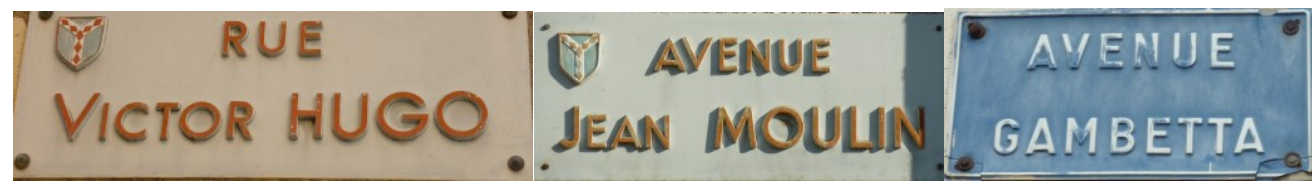

Figures 7, 8 and 9: Third Republic street signs, author's photos.

The pantheon is dominated by Third Republic heroes - the politicians Jean Jaurès and Léon Gambetta, the writer Victor Hugo and the scientist Louis Pasteur. Voltaire is the sole representative of an earlier period, and Jean Moulin 
the only representative of the war that ended the Third Republic (photos in Figures 7, 8 and 9). A further four individuals - Charles de Gaulle, Molière, Émile Zola and Marcel Pagnol - have their names commemorated in half the villages in the sample, but they fall well short of the popularity of the top six.

Table 2: Background of individuals commemorated

\begin{tabular}{|l|l|l|}
\hline & $\mathbf{\%}$ & Frequency (in descending order) \\
\hline Authors/Philosophers & 25 & $\begin{array}{l}\text { Victor Hugo, Voltaire, Molière, Émile Zola, Jean- } \\
\text { Jacques Rousseau, Blaise Pascal, Marcel Pagnol }\end{array}$ \\
\hline Politicians & 15 & $\begin{array}{l}\text { Jean Jaurnès, Léon Gambetta, Charles de Gaulle, } \\
\text { Jules Ferry, Georges Clemenceau, Louis Blanc }\end{array}$ \\
\hline Artists/Musicians & 14 & $\begin{array}{l}\text { George Brassens, Hector Berlioz, George Bizet, Marc } \\
\text { Chagall, Paul Cézanne, Jacques Brel }\end{array}$ \\
\hline Soldiers/Resistance & 13 & Jean Moulin, Marshal Leclerc, Foch \& Joffre \\
\hline Scientists/Engineers & 13 & $\begin{array}{l}\text { Louis Pasteur, Pierre \& Marie Curie, Paul Riquet, } \\
\text { Frères Lumière }\end{array}$ \\
\hline Revolutionaries & 12 & Mirabeau, Robespierre, Danton, Lafayette \\
\hline Ancient Regime & 5 & $\begin{array}{l}\text { Mainly saints \& church dignitaries, pre-revolutionary } \\
\text { soldiers and writers/philosopher }\end{array}$ \\
\hline Vigneron/Mayors & 3 & $\begin{array}{l}\text { Limited to town/village of domicile and local/ } \\
\text { regional significance only }\end{array}$ \\
\hline
\end{tabular}

Table 2 shows the professional background of all individuals commemorated in the sample of Languedoc streets. It is clear that authors and philosophers are the group most celebrated. In descending order, with 10 or more appearances, are Victor Hugo, Voltaire, Molière, Émile Zola and Marcel Pagnol. Following them, with 5 or more appearances, are Jean-Jacques Rousseau, Blaise Pascal, Anatole France and Diderot.

The artists and musicians most frequently celebrated in Languedoc street names are George Brassens, Hector Berlioz, Georges Bizet, Marc Chagall, Paul Cézanne and Jacques Brel (all with 5 or more appearances). The scientists and engineers most celebrated (10 or more mentions) are Louis Pasteur, Pierre and Marie Curie and Paul Riquet (engineer for the Canal du Midi). The soldiers and resistance fighters most celebrated in street names are Jean Moulin, and Marshals Leclerc, Foch and Joffre. The absence of Napoleon and his marshals is striking. The revolutionary figures most celebrated in street names are Mirabeau, Robespierre, Danton and Lafayette. The politicians and statesmen most celebrated in street names are Jean Jaurès, Léon Gambetta and Charles de Gaulle (with 10 or more streets named after them) and Jules Ferry, Georges Clemenceau and Louis Blanc (with 5 or more streets named after them).

While wine growers, businessmen and mayors collectively account for $5 \%$ of all street names, their celebrity is limited to the town/village of their domicile and none are celebrated in more than two streets. Similar observations can be made for figures from the Ancient Regime. 
It is of interest that only 3 percent of the people-named streets are named after women. Marie Curie is celebrated in 8 street names (but only in Sérignan does she appear without her husband, Pierre) followed by George Sand (6 streets), Saint Clair (4 streets), Marquise de Sévigné (3 streets) and Joan of Arc (3 streets). Those celebrated in only one street include the singer Edith Piaf and the writers, Nathalie Sarraute, Simone de Beauvoir and Marguerite Yourcenar.

\subsection{Events}

The principal events which are celebrated in Languedoc street names are the Revolution and the First and Second World Wars. Collectively, they account for 178 street names (13\%).

The great majority celebrate the Revolution. In addition to those Revolutionary individuals already identified (Table 2), the Revolution is also celebrated in those street names invoking its ideals and institutions. Table 3 shows the frequencies for each - in relation to the number of villages (out of 20), the number of streets overall and the prominence of these streets. The ubiquity of the République as a prefix or a suffix (e.g. Place or rue de le) is clear. It is also noteworthy that of the trinity - Liberty, Equality and Fraternity - it is Liberty that is most commemorated in street names.

Table 3: Revolutionary street names

\begin{tabular}{|l|l|l|l|}
\hline & $\begin{array}{l}\text { Number of } \\
\text { villages }\end{array}$ & $\begin{array}{l}\text { Number of } \\
\text { streets }\end{array}$ & $\begin{array}{l}\text { Main } \\
\text { thoroughfares }\end{array}$ \\
\hline Place/Avenue/rue de la République & 17 & 28 & 17 \\
\hline Rue Liberté & 13 & 14 & 10 \\
\hline Rue Égalité & 10 & 10 & 4 \\
\hline Rue Fraternité & 9 & 9 & 0 \\
\hline Rue Quatorze Juillet & 12 & 12 & 4 \\
\hline Rue Révolution & 9 & 11 & 3 \\
\hline $\begin{array}{l}\text { One or more months of the } \\
\text { Republican calendar }\end{array}$ & 7 & 15 & 0 \\
\hline $\begin{array}{l}\text { Other Revolutionary references such } \\
\text { as Convention, Jacobins, Girondins, } \\
\text { Brumaire }\end{array}$ & 10 & 12 & 0 \\
\hline
\end{tabular}

Table 4 reflects the influence of two World Wars on Languedoc street names. The number of villages commemorating martyrs of the Resistance and the total number of streets named after individual martyrs requires comment. Jean Moulin, de Gaulle's leader of the Resistance based in Béziers, is commemorated in 19 out of the 20 villages Other Resistance martyrs are rarely commemorated in more than one village. The villages of Capestang (centre of the Maquis de Fontjun) and Thézan-lès-Béziers each have no less than 9 streets named after Resistance martyrs. 
Table 4: World Wars street names

\begin{tabular}{|l|l|l|}
\hline & Number of towns & Number of streets \\
\hline Battles of Verdun, Somme and Marne & 14 & 17 \\
\hline Armistice Day (Onze Novembre) & 13 & 13 \\
\hline Paix/Victoire & 11 & 16 \\
\hline $\begin{array}{l}\text { French armies of Africa, Rhine and Danube, } \\
\text { Italian Expeditionary Corps }\end{array}$ & 12 & 13 \\
\hline Victory in Europe & 14 & 14 \\
\hline Martyrs de la Résistance (identified individually) & 19 & 3 \\
\hline
\end{tabular}

While the two World Wars are the most commemorated, the FrancoPrussian War of 1870/71 has also left a permanent mark on Languedoc towns and villages in the form of streets (15 in all) named for the lost regions of AlsaceLorraine and the cities of Metz, Strasbourg and Belfort. This war is also commemorated in streets named for Le Souvenir français, a voluntary organization created to preserve the memory of those who died in 1870/71, but later taking responsibility for the upkeep of all war graves. The Algerian War is commemorated in only three streets named for the date of its ending, Dix-neuf Mars 1962.

The only peace-time event to be celebrated in multiple street names is the 1907 Languedoc Winegrowers Revolt. The leader, Marcellin Albert, is commemorated in street names in 6 villages and Cecille Bourell, one of those killed by troops sent in to quell the Revolt, is remembered in a Pézenas street. The regiment which famously mutinied rather than firing on civilians - DixSeptième de Linge - is commemorated in a Montblanc street.

\section{Village profiles as revealed in street-name concentrations}

The focus now changes from analysis of the whole sample of 20 villages to a search for differences between them. Table 5 summarizes the data on commemorative names for each of the 20 villages.

Table 5: Percentage of commemorative street names by background of individuals commemorated

\begin{tabular}{|c|c|c|c|c|c|c|c|}
\hline & 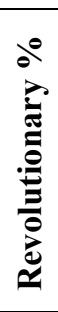 & 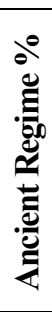 & 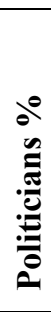 & 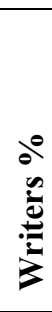 & 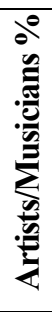 & 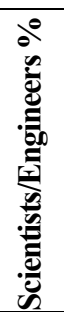 & 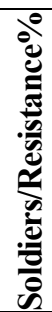 \\
\hline Bédiarieux & 4 & 20 & 14 & 8 & 12 & 9 & 8 \\
\hline Capestang & 14 & 9 & 11 & 21 & 4 & 12 & 20 \\
\hline Cazouls-lès-Béziers & 3 & 0 & 23 & 15 & 7 & 21 & 27 \\
\hline Clermont-l'Hérault & 7 & 6 & 11 & 31 & 9 & 14 & 11 \\
\hline Florensac & 36 & 4 & 12 & 21 & 6 & 8 & 7 \\
\hline
\end{tabular}




\begin{tabular}{|l|l|l|l|l|l|l|l|}
\hline Frontignan & 11 & 18 & 12 & 14 & 6 & 23 & 10 \\
\hline Gignac & 13 & 17 & 18 & 12 & 0 & 10 & 11 \\
\hline Lodève & 15 & 4 & 18 & 18 & 9 & 9 & 17 \\
\hline Marseillan & 10 & 5 & 13 & 24 & 18 & 10 & 15 \\
\hline Mèze & 6 & 5 & 24 & 24 & 10 & 11 & 20 \\
\hline Montagnac & 0 & 24 & 14 & 10 & 9 & 8 & 20 \\
\hline Montblanc & 10 & 10 & 10 & 38 & 4 & 9 & 10 \\
\hline Pézenas & 2 & 6 & 14 & 23 & 23 & 18 & 8 \\
\hline Puisserguier & 15 & 4 & 10 & 30 & 8 & 19 & 10 \\
\hline Sauvian & 7 & 8 & 9 & 45 & 24 & 0 & 5 \\
\hline Sérignan & 7 & 2 & 10 & 18 & 36 & 4 & 4 \\
\hline Servian & 4 & 0 & 18 & 42 & 18 & 10 & 5 \\
\hline Thézan-lès-Béziers & 5 & 6 & 10 & 31 & 2 & 14 & 23 \\
\hline Vias & 10 & 0 & 15 & 32 & 2 & 15 & 22 \\
\hline Villeneuve-lès-Béziers & 15 & 7 & 20 & 24 & 4 & 12 & 21 \\
\hline
\end{tabular}

The first column shows the percentage of street names commemorating the Revolution in each village. From a sample mean of $12 \%$, the variance between Florensac (36\%) and Montagnac $(0 \%)$ is substantial. Similarly, with the second column showing the percentage of street names commemorating people and institutions from before the Revolution - referred to collectively as the Ancient Regime - the range is again substantial, from Vias and Cazoulslès-Béziers $(0 \%)$ to Montagnac $(24 \%)$. Columns 3 to 7 show the percentages of individuals from different professional backgrounds which are commemorated in the street names of each of the 20 villages. Overall, the variances are similar to those observed in columns 1 and 2 . While the numbers are small, they do suggest that some villages can be said to have distinct profiles - solely on the basis of their street names. For example, Florensac might be said to have a "Revolutionary" profile, while Sérignan has more of an "Artists/Writers" profile. These, and other profiles, are explored further in Figures 10, 12 and 16.

Figure 10 has a "Revolutionary" vertical axis (based on the percentage of street names commemorating the Revolution and an "Ancient Regime" horizontal axis (based on percentage of street names commemorating prerevolutionary figures and institutions). The diagonal line indicates equal representation on both axes i.e. no bias in either direction. The majority of the 20 villages (indicated by circles) lie above the diagonal, indicating the greater frequency of Revolutionary over Ancient Regime street names. 


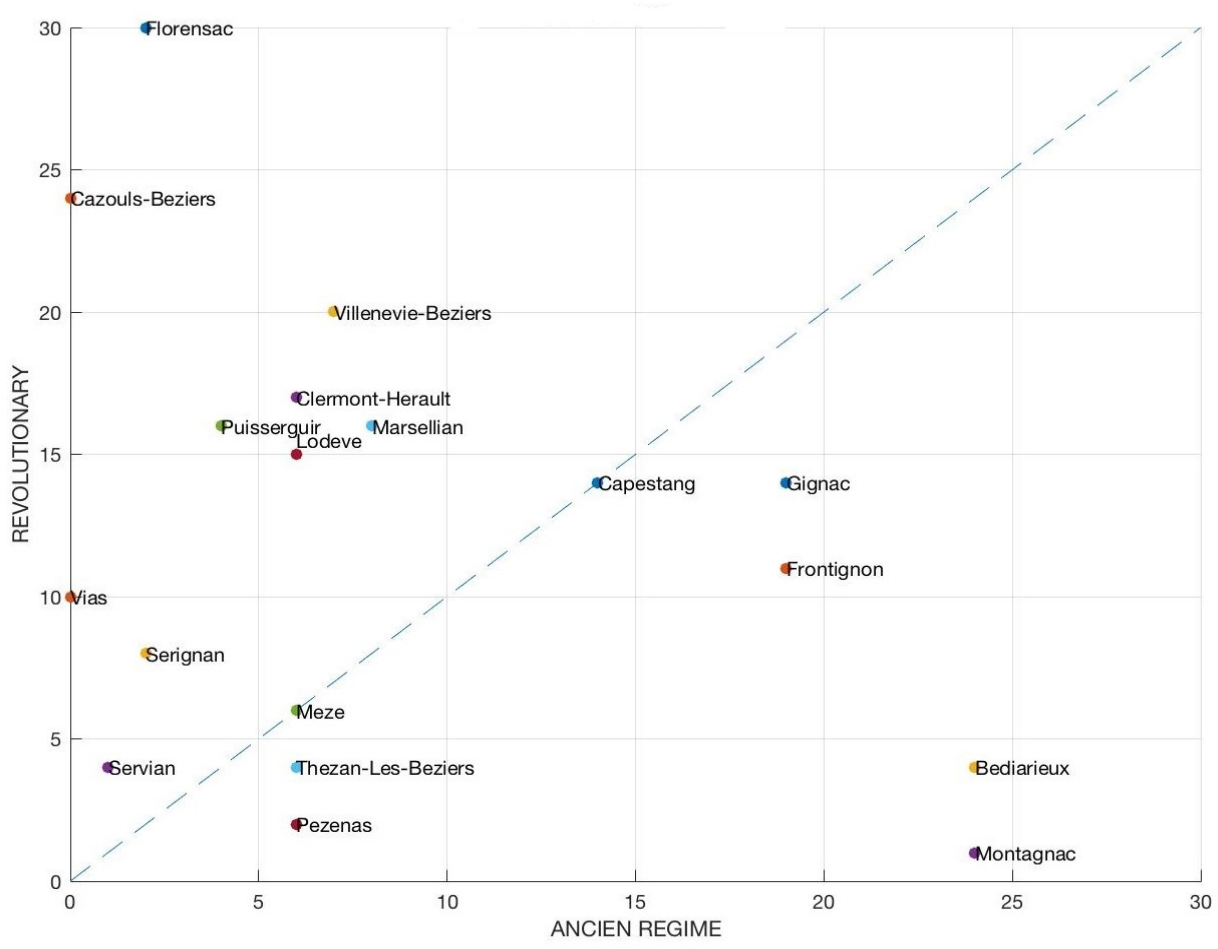

Figure 10: Town street names in relation to Revolutionary commemoration and Ancient Regime commemoration

The outliers are of greatest interest. Florensac, at the top of the vertical axis, and Montagnac, near the extreme of the horizontal axis, merit further exploration.

Florensac is one of the few towns in the Languedoc sample that still has street names commemorating the months of the Republican calendar Vendémiaire, Brumaire, Ventôse, Germinal, Floréal, Prairial, Messidor, Thermidor and Fructidor. It also has streets celebrating Mirabeau and Marat and the Coup d'État of the 18th Brumaire. It has a Place de la République, a rue de la République, a Place de la Liberté and a rond-point de la Liberté. It is one of the few towns to name a street for the date of the proclamation of the Third Republic (rue Quatre Septembre) and its Marianne, erected in 1882, standing on a 4-metre plinth, totally dominates the tree-lined Place de la République. Perhaps significantly, in view of this republican emphasis, Florensac is one of the few villages with no street named after Charles de Gaulle. It may also be significant that Florensac is twinned with Anxi in China, twinning unique in Languedoc.

Since 2011, visitors entering the town from Saint-Thibéry have been confronted by a 30 -metre mural depicting people helping each other - men and women, young and old - and symbolising the enduring ideals of the Revolutionary trinity - Liberté, Egalité and Fraternité. 


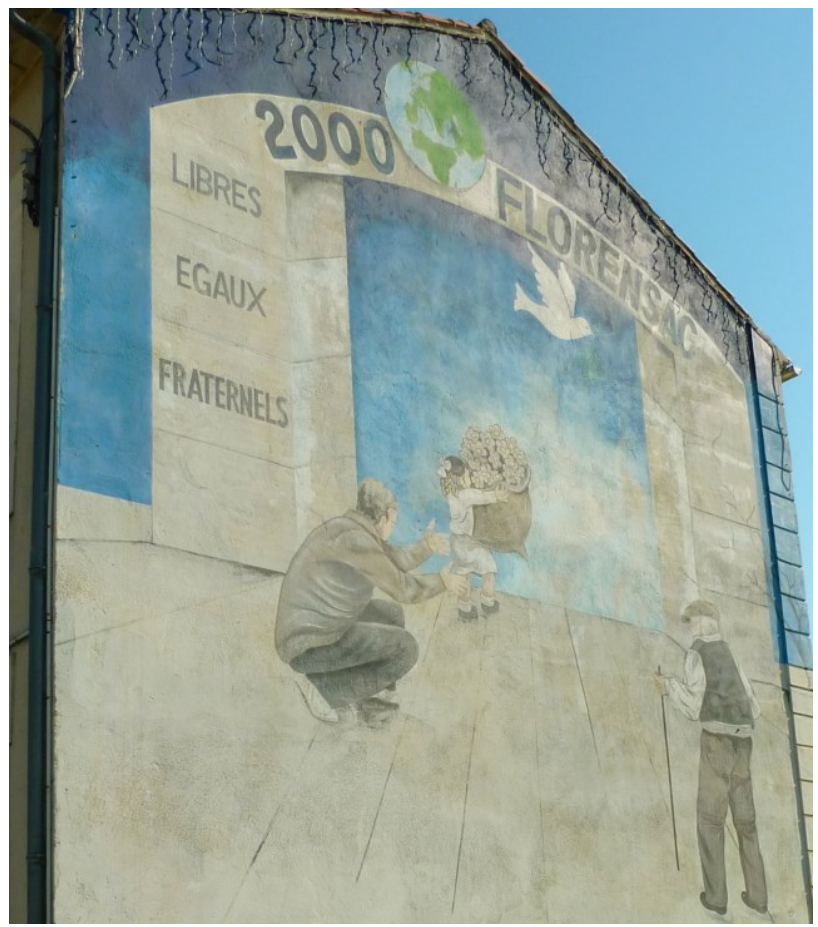

Figure 11: Florensac gable-end mural, author's photo.

How to explain this concentration? Florensac had one of the earliest (1791) and most active political societies in Hérault, and from the 1870s onwards has had a succession of mayors who were either Parti Republican (CRAD), Section française de International Ouvrière (SFIO), Parti Communiste (PCF) or Parti Socialiste (PS).

Montagnac is unique among the 20 towns/villages in not having either a rue de la République or a rue de la Liberté. The only street having any possible reference to the Revolution is one named after the Marquis de la Fayette - arguably an exponent of the ideals of the Enlightenment rather than the Revolution. The only Third Republic figure commemorated is Jean Jaurès. By contrast, there are twelve streets named after religious buildings (Catholic and Protestant) and further streets named for Saint Clair, Saint Eloi, and Saint Jacques and for other Ancient Regime figures such as the 17th-century poet Jean de la Fontaine and the Royalist general Francoise Marceau. It may also be significant that Montagnac boasts a Gloriette, an 18th-century ornamental feature, rather than a Marianne.

Again, it is difficult to explain this concentration, but Montagnac was part of the Royal estates until 1790 and for a time it remained associated with the Prince Conti and the landed - families d'Alzon, de Puységur and d'Aulan. Those holding mayoral office have included the Marquis de Vissac, Comte de Puységur and Anatole Ducros de Saint-Germain. More recent mayors have tended to stand as independents rather than representatives of any political party. 
Figure 12 has a "Men of Ideas" vertical axis (showing the percentage of street names commemorating writers, artists and musicians) and a "Men of Action" horizontal axis (showing the percentage of street names commemorating politicians and soldiers).

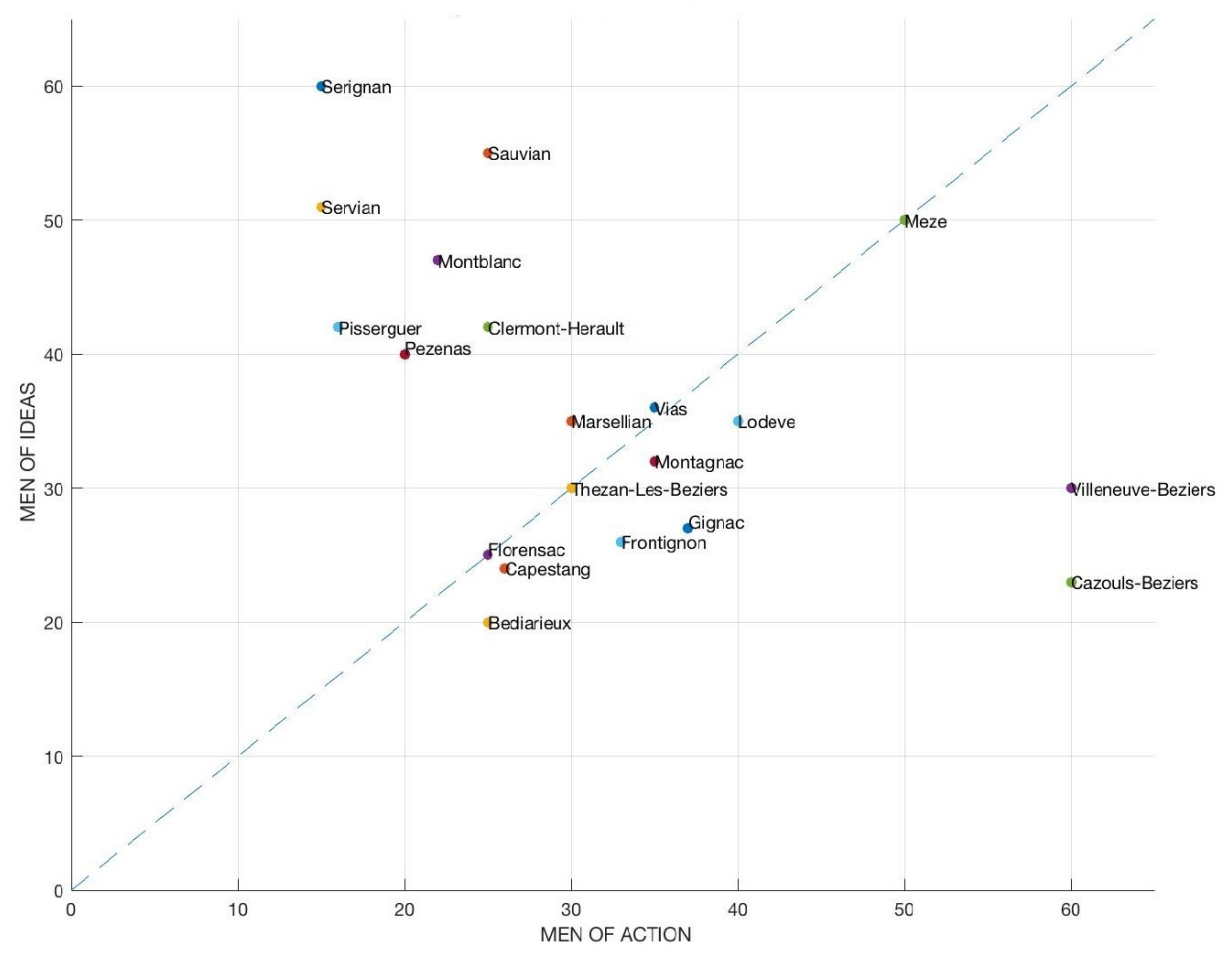

Figure 12: Town street names in relation to Men of Ideas commemoration and Men of Action commemoration

Again, the diagonal indicates equal representation on both axes. As in the previous diagram, it is the outliers which are of greatest interest. Sérignan and Sauvian, at the top of the vertical axis and Cazouls-lès-Béziers and Villeneuve-lès-Béziers on the extreme end of the horizontal axis.

Sérignan. Over half of the commemorative street names in this town celebrate writers, artists and musicians. The writers celebrated, 23 in all, range from those writing before the Revolution (such as Jean de La Fontaine, JeanJacques Rousseau and Montesquieu and Rabelais) to post-Second War writers (such as Albert Camus, Jean-Paul Sartre and André Malraux). The artists celebrated -18 in all - are mainly 19th century (e.g. Pierre Bonnard, Claude Monet, Paul Gauguin and Edgar Degas). The musicians - 16 in all - range from such 18th-century composers as Philippe Rameau and Rouget de Lisle, to 20th-century favourites such as George Brassens and Jacques Brel. 


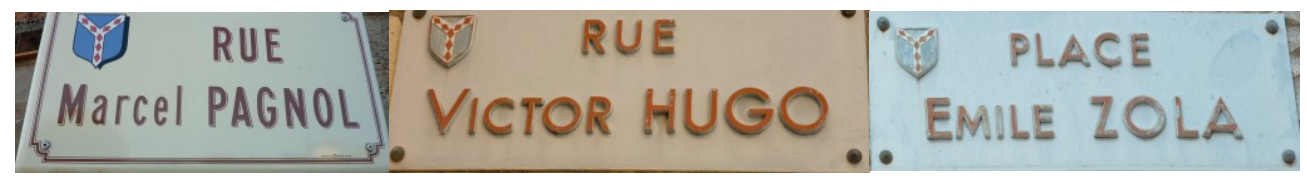

Figures 13, 14 and 15: Third Republic street signs, author's photos.

Given the influence that Mayors have on street-naming, it is perhaps significant that Sérignan has had three long-serving Mayors, including André Gélis (1998-2008) who was the force behind the Muse d'Art Contemporain. It may also be relevant that the artist/designer, André Oulié (1898-1996) was a long-term resident.

Cazouls-lès-Béziers. Of all towns in the sample, Cazouls-lès-Béziers shows the greatest propensity to commemorate "Men of Action" - soldiers, politicians and applied scientists. The soldiers commemorated include no less than 7 Revolutionary marshals and generals (Augereau, Bara, Championnet, Dessaix, Hoche, Kléber) and Rouget de Lisle, the author of the Marseillaise. Also commemorated are the Third Republic generals - Amédée Courbet, Villebois-Mareuil and Sébastian Lespès -, all of whom distinguished themselves in colonial wars. Of the politicians commemorated, those from the Third Republic predominate - Sadi Carnot, George Clemenceau, Jules Ferry, Léon Gambetta Jean Jaurès and Waldeck-Rousseau. Also commemorated is Paul Best, Minister of Education in Gambetta's cabinet, who achieved notoriety through his campaign against the circulation of religious tracts, particularly prevalent in the south of France. Revolutionary politicians commemorated include Camille Desmoulins, Fabre d'Églantine, Honoré Mirabeau and Pierre Vergniaud. The scientists commemorated in Cazouls-lèsBéziers street names include André Ampère (discoverer of electromagnetism), François Arago (astronomer), Amédée Borrel (biologist) and Jean-François La Pérouse (geographer and explorer).

There is no obvious reason why the streets of Cazouls-lès-Béziers should particularly commemorate soldiers, politicians and applied scientists other than the possibility that a succession of Mayors favoured "Men of Action". Since the Second World War all Mayors of Cazouls-lès-Béziers have been members of the Parti Socialiste.

Figure 16 has an "International" vertical axis (showing the percentage of street names having an international significance) and "Regional/Local" horizontal axis (showing the percentage of street names having only a local or regional significance). As in the previous diagrams, it is the outliers which are of greatest interest. Montblanc, Pézenas, Frontignan, Marseillan and Sérignan have street names with the strongest international flavour. As far as Frontignan and Marseillan are concerned, this is probably accounted for by their maritime connections with the rest of the Mediterranean and beyond (such as rues Belgique, Italie, Majorque, Venice, Portugal, Marocain and Argentine). The 
international flavour of street names in Sérignan, Pézenas and Montblanc principally derives from their propensity to commemorate foreign artists, writers and statesmen (such as Benjamin Franklin, Nelson Mandela, Albert Schweitzer, Nicolas Copernic and Albert Einstein).

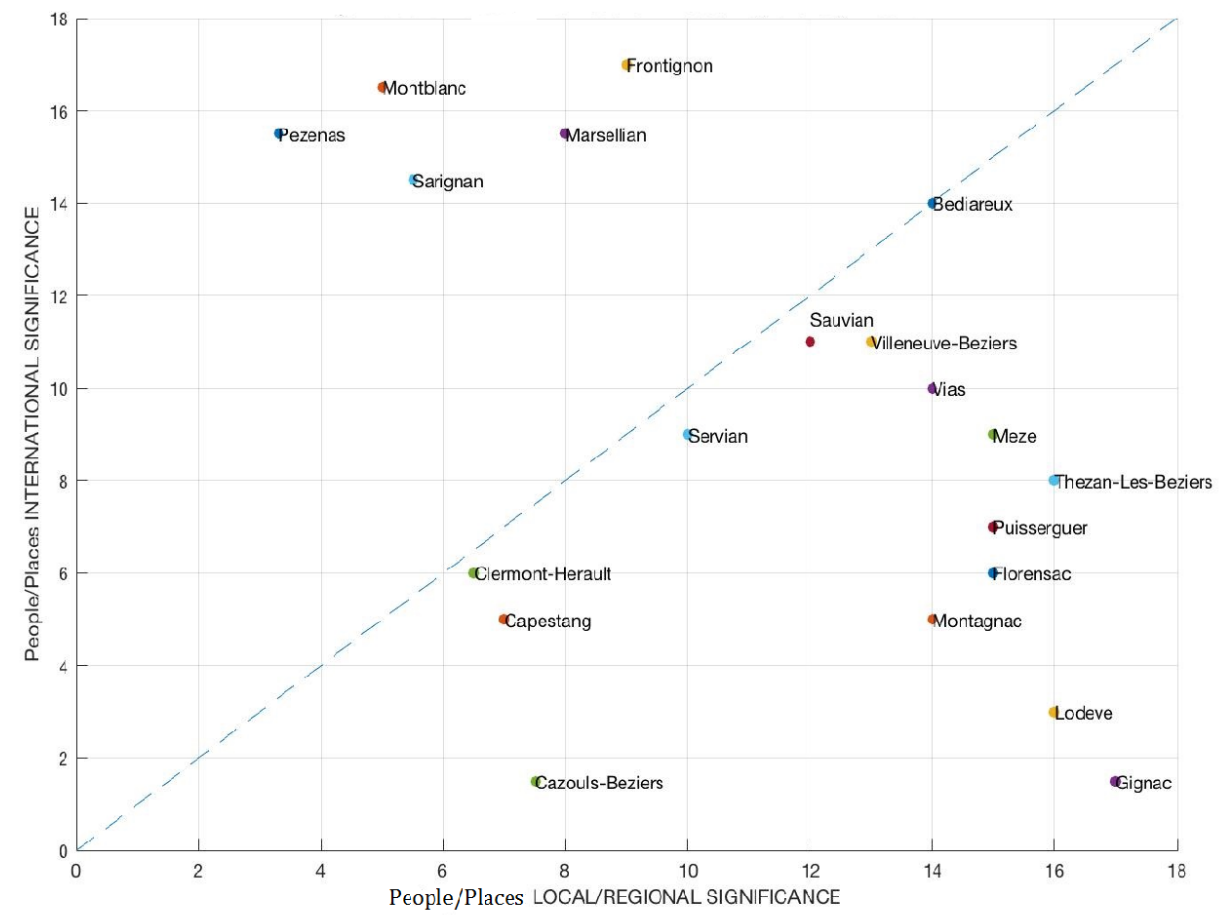

Figure 16: Town street names in relation to International Significance commemoration and Regional/Local Significance commemoration

Gignac. This town has streets commemorating Midi-writers (e.g. Frédéric Mistral), politicians (e.g. Henri Brissac), soldiers (e.g. Colonel Delmas or Marc Gaultier) and wine growers (e.g. Paul Ronmagnac or Gustave Seranne), but few of them were or are known outside Languedoc. Over the years, it is as if Gignac has made a succession of commemorative choices: Pierre Mendès-France rather than Charles de Gaulle, Marcelin Albert rather than Jean Jaurès, Frédéric Mistral rather than Victor Hugo. Of all the people commemorated on Gignac's streets, only Joan of Arc and, arguably, Georges Clemenceau can be considered to be international figures.

There are no obvious explanations for this local/regional bias, except perhaps, location. Gignac, like Lodève, is located far from the coast, which gives Marseillan and Frontignan street names an international flavour. Before the blasting of the A75 through the southern edge of the Massif Central, both Lodève and Gignac must have been comparatively remote, and it is perhaps this remoteness which is reflected in their street names. 


\section{Languedoc and France}

The foregoing analysis has been exclusively on street names in Languedoc and the question inevitably arises, to what extent are the findings typical of France as a whole?

Daniel Milo's analysis of street names in 95 prefectures across France (Nora 1986, vol. 3) provides a useful comparator. The rankings of the top ten names in the two studies is shown below:

20 Languedoc villages
Victor Hugo
Voltaire
Jean Jaurès
Louis Pasteur
Jean Moulin
Charles de Gaulle
Léon Gambetta
Molière
Émile Zola
Marcel Pagnol

\author{
95 Prefectures \\ Victor Hugo \\ Léon Gambetta \\ Jean Jaurès \\ Louis Pasteur \\ Marshal Leclerc \\ Georges Clemenceau \\ Marshal Foch \\ Charles de Gaulle \\ Carnot \\ Jeanne d'Arc
}

Those common to the two rankings are the Third Republic politicians, Jean Jaurès and Léon Gambetta; the writer, Victor Hugo; the scientist Louis Pasteur; and the statesman, Charles de Gaulle.

The appearance in the Languedoc but not the National ranking of the Pézenas-based, Molière, and the Midi writer, Marcel Pagnol, are understandable, but why Voltaire and Émile Zola are more celebrated in Languedoc than in the rest of France is more difficult to understand. The prominence of Jean Moulin in the Languedoc ranking - and his complete absence in the top 25 of the national ranking is probably accounted for by his crucial role in promoting the myth that all French had stood united in the Resistance against the common enemy who were assisted by only a handful of collaborators. This myth, fully explored by Henry Russo (The Vichy Syndrome, 1991), operated throughout France, but it was especially powerful in those areas, like Languedoc, which had been under Vichy control.

Looking at those appearing in the national ranking but are absent from the Languedoc ranking, it is difficult to explain why Marshals Foch and Leclerc should be more celebrated nationally. The appearance of Carnot is a mystery, although it could be accounted for a conflation of three Carnot's Lazare, organizer of the Republican armies (1753-1823), his son and famous scientist, Nicolas (1796-1832), and his grandson, Sadi (1837-1894), who was briefly President of the Third Republic. In the Languedoc sample they have been separately accounted. 
Overall, the similarities between the two rankings are more impressive than the differences and they permit some general conclusions.

First, the street names of France reveal the powerful influence of the Third Republic. This is probably accounted for by two factors - the spectacular urban growth over the second half of the Third Republic and the longevity of the Third Republic itself. It lasted longer than the Consulate, Empire, Restoration, July Monarchy, Second Republic and Second Empire combined.

Second, the street names of France reveal a national esteem for writers and thinkers. This may be considered particularly appropriate for a nation, which places such value on the word and virtually identifies language with civilization. But while all writers are esteemed, those who employ their genius to political ends seem to be esteemed most of all. The high ranking of both Victor Hugo and Émile Zola is probably accounted for by their support for Republican causes.

Third, while particularly commemorating individuals, French street names also commemorate those events, places and values, which symbolize the French Republique. In Languedoc and in the 95 Prefectures throughout France, streets containing the word Republic outnumber all other commemorative street names. Moreover, whether prefixed by Avenue, or Boulevard or Place or rue, these are invariably main thoroughfares. Streets named for Liberté and Victoire are also accorded prominent urban locations.

Fourth, as well as celebrating national identity, French street names also register national turbulence and change. For each succeeding regime, street naming has served a triple function - a means of propaganda, an instrument of revenge and a form of legitimation. The Revolution set the pattern of baptisms and re-baptisms but these were followed by further bouts in 1815, 1830, and 1848 and in 1870, ending in 1945 with the removal of most vestiges of Vichy, including over 200 streets named after Petain ${ }^{3}$.

The process continues in the naming and re-naming of streets to better reflect France's increasingly diverse social structure.

3 Most of the streets named for Petain were re-named for Charles de Gaulle, but those leftleaning towns and villages hostile to de Gaulle tended to opt for neutral names, such as Liberation and Victoire. The last French village to retain a street named for Petain was Belrain, near Verdun. In 2013 the name was changed by the simple addition of the prefix, Marechal, to indicate that the village was honouring his role in the First World War, rather than as head of Vichy. 


\section{References}

Ainiala, Terhi \& Vuolteenaho, Jani (eds.). 2009. Urban place names: International Symposium. Helsinki: Research Institute for the Languages of Finland.

Felecan, Oliviu. 2013. Foreword. In Felecan, Oliviu \& Bugheșiu, Alina (eds.), Onomastics in contemporary public space, X-XV. Newcastle upon Tyne: Cambridge Scholars Publishing.

Felecan, Oliviu \& Felecan, Daiana (eds.). 2014. Unconventional anthroponyms: Formation and discursive function. Newcastle upon Tyne: Cambridge Scholars Publishing.

Grégoire, Abbé H. 1794. Systeme de denominations topographiques pour les rues. Paris: Comite de l'Instruction publique.

Lacombe, P. 1886. Les noms des rues de Paris. Revue de la Révolution 7, 104.

Morand, R. 1906. On the instruction of the masses through things of greatest utility: Street signs. Paris: Conseil Municipal de Paris.

Nora, Pierre. 1986. Les lieux de mémoire, 3 vols. Paris: Gallimard. (Translated into English as Realms of memory, University of Chicago Press, 19961998.)

Rose-Redwood, Reuben \& Alderman, Derek \& Azaryahu, Maoz (eds.). 2018. The political life of urban streetscapes. Oxford/New York: Routledge.

Russo, H. 1991. The Vichy Syndrome. Harvard University Press.

Taylor, Rex. Forthcoming. Street names and urban identities: An exploratory study between Montblanc, France and Dumfries, Scotland. Journal of Scottish Name Studies. 